\title{
Levamisole on the biochemical and hematological responses to parasitism by monogenoids in dog snapper
}

\author{
Bruno De Laquila Oliveira ${ }^{*}$ (D) Rodrigo Matos de Souza ${ }^{2}$ Jorge Pinto da Silva Filho ${ }^{3}$ \\ Halysson Pena Ribeiro ${ }^{2}$ Deusélio Bassini Fioresi ${ }^{4}$ Levy de Carvalho Gomes ${ }^{5}$ \\ Luiz Fernando Loureiro Fernandes ${ }^{3}$
}

${ }^{1}$ Programa de Pós-Graduação em Oceanografia Ambiental, Universidade Federal do Espírito Santo (UFES), 29199-970, Aracruz, ES, Brasil. E-mail: brunodlo@yahoo.com.br. ${ }^{*}$ Corresponding author.

${ }^{2}$ Laboratório de Cultivo de Organismos Marinhos, Base Oceanográfica, Universidade Federal do Espírito Santo (UFES), Aracruz, ES, Brasil. ${ }^{3}$ Departamento de Oceanografia e Ecologia, Universidade Federal do Espírito Santo (UFES), Vitória, ES, Brasil.

${ }^{4}$ Instituto Federal de Educação, Ciência e Tecnologia do Espírito Santo (IFES), Venda Nova do Imigrante, ES, Brasil.

${ }^{5}$ Universidade Vila Velha (UVV), Vila Velha, ES, Brasil.

ABSTRACT: The response of biochemical and hematological parameters were analyzed in dog snapper (Lutjanus jocu) grown in net cages, as well as for the specimens kept in the laboratory during an infestation by Neobenedenia melleni, and after treatment with freshwater bath and injectable application of levamisole. Significant changes were observed in N. melleni parasitized individuals, characterized by increased glucose and lactate levels, as well as a significant fish hematocrit reduction and leukocyte increase. Treatment with freshwater baths, concomitant with injectable levamisole application, showed therapeutic efficacy in several parameters after 14 days of treatment.

Key words: aquaculture, biochemistry, hematology, Neobenedenia melleni, fish.

Efeito do levamisol na resposta bioquímica e hematológica ao parasitismo por monogenoides em dentão

RESUMO: A resposta de parâmetros bioquímicos e hematológicos foram analisadas no dentão (Lutjanus jocu) cultivados em tanque-rede, bem como os exemplares mantidos em laboratório durante a infestação por Neobenedenia melleni e após o tratamento com banho de água doce e aplicação injetável de levamisol. Foram observadas alterações significativas nos individuos parasitados por $N$. melleni, caracterizado pelo aumento dos niveis de glicose e lactato, bem como significativa redução em hematócrito e aumento em leucócito dos peixes. O tratamento com banhos de água doce, concomitante à aplicação injetável de levamisol, evidenciou eficácia terapêutica em diversos parâmetros após 14 dias de tratamento.

Palavras-chave: aquicultura, bioquímica, hematologia, Neobenedenia melleni, peixe.

Monogenoids parasites recorded in Brazil, Neobenedenia melleni in particular, have been known to cause losses, like partial or total mortality of the cultured individuals (KERBER et al., 2011; SILVA et al., 2014). A study on the occurrence of monogenoids and the proposition of treatments in cultured marine fishes is still incipient and there are few articles published for Lutjanidae (LIANG et al., 1992; FAJER-ÁVILA et al., 2007; DEL RIO-ZARAGOZA et al., 2010; DEL RIO-ZARAGOZA et al., 2011).

Effective treatments are available for the elimination of monogenoids in marine fish, including the immersion of the fish in freshwater from $5 \mathrm{~min}$ (SANCHES et al., 2007) up to 60 minutes (FAJERÁVILA et al., 2007). The use of specific drugs has also been explored to treat these fish pathogens, such as levamisole, a popular antiparasitic (PETRILLO et al., 2017). The immunomodulatory capacity of levamisole can be used to control pathogenic infections and reduce the harmful effects of stress in fish farming (BILLER-TAKAHASHI et al., 2016).

Due to its high market value and as its present declining population, dog snapper is an important marine species to be studied, as well as its rusticity and adaptability in aquaculture (LINDEMAN et al., 2016). The aim of this study was to investigate the effects of levamisole in the physiological responses of Lutjanus jocu infested with Neobenedenia melleni.

Forty fish $(220 \pm 68 \mathrm{~g}$ and $24.5 \pm 2.5 \mathrm{~cm}$ total length) were collected at the Piraquê-açu 
estuary, Aracruz / ES, southeastern Brazil (1956'S $40^{\circ} 10^{\prime} \mathrm{W}$ ), through a gillnet (Authorization for activity for scientific purposes of ICMBio, SISBIO number 52082-2), and transferred to a $4 \mathrm{~m}^{3}$ cage, also located in the estuary. After the 30-day acclimation period, seven specimens were collected. At the time they were taken out of the cage, they were sedated using benzocaine $\left(50 \mathrm{mg} \mathrm{L}^{-1}\right)$ and blood was collected immediately via caudal puncture. Next, the remaining fish were transferred to the Marine Organisms Rearing Laboratory of the Universidade Federal do Espírito Santo (Protocol 96/2015 of the Ethics Committee for the Use of Animals CEUA / UFES).

In the laboratory, the fish were transferred to $6.000 \mathrm{~L}$ tanks, provided with Recirculating Aquaculture System (RAS). Mean values of temperature $23.5 \pm 0.8^{\circ} \mathrm{C}, \mathrm{pH} 7.82 \pm 0.65$, dissolved oxygen $5.69 \pm 0.4 \mathrm{mg} \mathrm{L}-1$ and salinity $34.85 \pm 0.4$ were measured with a YSI Professional Plus probe. After forty days in the laboratory, fish were observed to refuse food, presented erratic and lethargic swimming, showed signs of secondary infection such as hemorrhagic lesions (ulcers) and fin erosion. Exophthalmia was also visible, with opacity and intraocular hemorrhage (Figure 1).

On parasitic examination, 21 fish revealed the presence of monogenoid parasites. These parasites were then collected, fixed, quantified, and analyzed under a stereoscopic microscope. Utilizing the key proposed by ERNST \& WHITTINGTON (1996), the Neobenedenia melleni parasite was identified. The infected fish were then removed and placed in $500 \mathrm{~L}$ tanks for five days, and seven specimens were randomly selected and anesthetized with benzocaine $(50 \mathrm{mg} / \mathrm{L})$ prior to blood withdrawal.
In order to remove the monogenoid parasites, the remaining fish were placed in freshwater baths for $15 \mathrm{~min}$ (KERBER et al., 2011). Subsequently, under the trinocular microscope, the parasites were measured having between 2 and $4 \mathrm{~mm}$ in total length, with $82 \pm 23$ of them, on average, present per fish. A second bath was performed on the next day after the first freshwater bath, and at this time no parasites were recorded. Immediately after the freshwater baths, the fish were separated into two groups, each having seven individuals, and placed in $500 \mathrm{~L}$ tanks.

The first group was administered levamisole (Levamisole-Ripercol ${ }^{\circledR}$ Chloridate), diluted in physiological solution, the injection being equivalent to $5 \mathrm{mg} \mathrm{kg}^{-1}$ of live weight and given in the dorsal muscle at the beginning of the dorsal fin. The second group was administered a saline injection (control), to simulate similar stress as in the levamisole treatment. After 14 days, fish from both treatments were anesthetized prior to blood withdrawal, and biochemical and hematological analyses were performed. Subsequently, a comparative study was done between the two groups (control and infected fish).

The blood was centrifuged in heparinized microcapillary tubes and the hematocrit reading (\%) was determined. Dilutions of 1:200 in dye solution (Na2 EDTA, formaldehyde, $\mathrm{NaCl}, \mathrm{NaOH}$, methylene blue) were examined to identify the erythrocyte count and the counting was done directly in a Neubauer chamber under an optical microscope (Olympus CX41). The differential and total counts of the leukocytes and thrombocytes were noted using dry blood samples, fixed and stained with rapid panoptic dye (RENYLAB ${ }^{\circledR}$ commercial kit, Brazil), and counted by the indirect method.

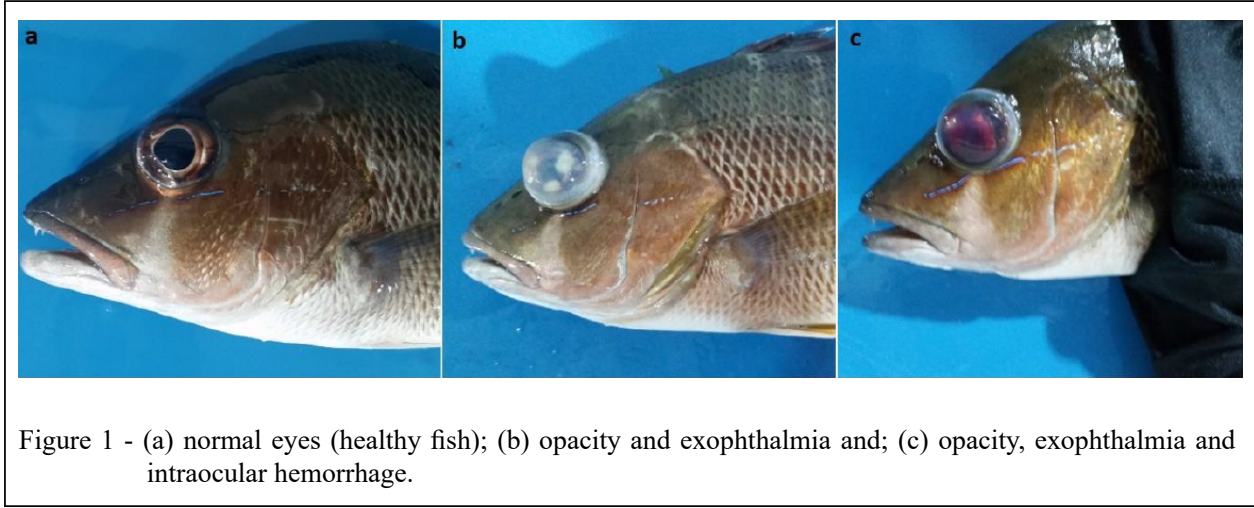

Ciência Rural, v.49, n.9, 2019. 
Plasma glucose and hemoglobin concentrations (commercial kit, Bioclin ${ }^{\circledR}$, Brazil) and plasma lactate (commercial kit, BioTecnica ${ }^{\circledR}$, Brazil) were recorded after employing the colorimetric method and spectrophotometer analysis.

For each parameter the statistical analysis was done separately using ANOVA. Results of groups (treatments) were compared using the Tukey test $(p<0.05)$ and the final values are given as the means and standard deviation with the analyses performed using the PAST 2.17software.

Table 1 lists the biochemical and hematological parameters of $L$. jocu. The hematocrit, lymphocyte and thrombocyte values indicated the efficacy of the levamisole compared to the levamisole control, returning values significantly equal to the control group. The leukocytes and neutrophils revealed no difference between both the levamisole and levamisole control; however, the treatment with levamisole revealed that the levels returned to values significantly equal to those of the control group. $\mathrm{MCV}$ and $\mathrm{MCH}$ showed no significant difference between treatment with levamisole and levamisole control, but levamisole group showed a difference from the infected fish group. From Table 1 it is clear that a significant difference was present in the glucose and lactate values, between the control and infected fish, and both parameters showed regression in the levamisole-treated group.

In the laboratory, the infestation by $N$. melleni induced physiological reactions in the dog snapper, with progressive results, mainly in terms of food refusal, to more severe instances of temporary blindness due to exophthalmia and intraocular hemorrhage. Hematological and biochemical manifestations reported in this study in $L$. jocu and diseases caused by monogenoids reported in the literature, including for snappers, such as in spanish flag snapper (Lutjanus carponotatus)(ERNST \& WHITTINGTON, 1996), rose snapper (Lutjanus guttatus) (DEL RIO-ZARAGOZA et al., 2011), revealed vulnerability of the genus to monogenoids during periods of confinement.

The pathogen-induced stress conditions in the present study revealed elevated glucose and lactate levels, implying that monogenoid parasitism stimulates the high plasma glucose levels as a physiological defense response. These results concurred with the monogenoid infestation-induced high glycemic levels in the Lutjanus guttatus (DEL RIO-ZARAGOZA et al., 2011) and Pangasianodon hypophthalmus (KUMAR et al., 2018). Plasma

Table 1 - Hematological and biochemical parameters of the dog snapper (Lutjanus jocu) in cage prior to being infected, during infestation of N. melleni and 14 days post levamisol treatment $(5 \mathrm{mg} / \mathrm{kg})$.

\begin{tabular}{|c|c|c|c|c|c|}
\hline Parameter & Control & Infected Fish & Levamisole Control & Levamisole & $\mathrm{P}$ value \\
\hline \multicolumn{6}{|c|}{ } \\
\hline Hemoglobin $\left(\mathrm{g} \mathrm{dL}^{-1}\right)$ & $13.93 \pm 1.30 \mathrm{a}$ & $12.70 \pm 0.81 \mathrm{a}$ & $13.31 \pm 0.46 \mathrm{a}$ & $13.59 \pm 0.80 \mathrm{a}$ & 0.0997 \\
\hline Erythrocytes $\left(10^{6} \mathrm{~mm}^{3}\right)$ & $2.6 \pm 0.52 \mathrm{ab}$ & $3.0 \pm 0.72 \mathrm{a}$ & $2.2 \pm 0.28 \mathrm{~b}$ & $2.0 \pm 0.33 \mathrm{~b}$ & 0.0068 \\
\hline Hematocrit $(\%)$ & $45.7 \pm 4.5 \mathrm{a}$ & $35.5 \pm 7.0 \mathrm{~b}$ & $32.6 \pm 5.4 \mathrm{~b}$ & $40.75 \pm 4.5 \mathrm{a}$ & 0.0017 \\
\hline Leukocyte $\left(10^{3} \mu \mathrm{L}^{-1}\right)$ & $47.07 \pm 18.86 \mathrm{~b}$ & $117.0 \pm 30.56 \mathrm{a}$ & $76.15 \pm 36.52 \mathrm{ab}$ & $86.07 \pm 22.67 \mathrm{ab}$ & 0.0037 \\
\hline Neutrophils (\%) & $14.60 \pm 4.34 \mathrm{c}$ & $33.86 \pm 9.01 \mathrm{a}$ & $30.86 \pm 10.75 \mathrm{ab}$ & $18.14 \pm 12.02 \mathrm{bc}$ & 0.0047 \\
\hline Lymphocytes (\%) & $75.40 \pm 5.18 \mathrm{a}$ & $52.57 \pm 11.06 \mathrm{~b}$ & $60.0 \pm 6.51 \mathrm{~b}$ & $75.14 \pm 11.77 \mathrm{a}$ & 0.0003 \\
\hline Monocytes (\%) & $10.0 \pm 6.16 \mathrm{a}$ & $13.57 \pm 8.62 \mathrm{a}$ & $9.14 \pm 5.55 \mathrm{a}$ & $6.71 \pm 2.87 \mathrm{a}$ & 0.2597 \\
\hline Thrombocytes $\left(10^{3} \mu \mathrm{L}^{-1}\right)$ & $29.48 \pm 10.64 b$ & $55.17 \pm 8.54 \mathrm{a}$ & $51.12 \pm 6.68 \mathrm{a}$ & $37.39 \pm 9.21 \mathrm{~b}$ & 0.0001 \\
\hline $\operatorname{MCV}\left(\mu \mathrm{L}^{-1}\right)$ & $182.54 \pm 47.90 \mathrm{a}$ & $121.65 \pm 21.54 \mathrm{~b}$ & $150.42 \pm 36.88 \mathrm{ab}$ & $188.47 \pm 30.61 \mathrm{a}$ & 0.0059 \\
\hline $\mathrm{MCH}(\%)$ & $55.96 \pm 15.50 \mathrm{ab}$ & $45.31 \pm 13.68 \mathrm{~b}$ & $61.10 \pm 8.14 \mathrm{ab}$ & $68.53 \pm 10.14 \mathrm{a}$ & 0.0109 \\
\hline $\mathrm{MCHC}\left(\mathrm{g} \mathrm{dL}^{-1}\right)$ & $30.72 \pm 4.74 \mathrm{a}$ & $37.21 \pm 8.83 \mathrm{a}$ & $41.76 \pm 6.56 \mathrm{a}$ & $36.88 \pm 6.21 \mathrm{a}$ & 0.0870 \\
\hline \multicolumn{6}{|c|}{ } \\
\hline Glucose $\left(\mathrm{g} \mathrm{dL}^{-1}\right)$ & $74.36 \pm 15.52 \mathrm{c}$ & $123.26 \pm 19.01 \mathrm{a}$ & $113.89 \pm 27.21 \mathrm{ab}$ & $85.83 \pm 16.24 b c$ & 0.0010 \\
\hline Lactate $\left(\mathrm{g} \mathrm{dL}^{-1}\right)$ & $9.33 \pm 1.77 \mathrm{~b}$ & $16.04 \pm 2.25 \mathrm{a}$ & $14.70 \pm 2.82 \mathrm{a}$ & $10.95 \pm 2.42 \mathrm{~b}$ & 0.0002 \\
\hline
\end{tabular}

Mean \pm SD. Different letters ( $a, b$ or $c)$ indicate a significant difference $(\mathrm{p}<0.05)$ between the groups.

Control: Fish cultured in the cage; Infected Fish: N. melleni-infected fish; Levamisole Control: collection 14 days post exposure to infected fish and application of the levamisole-free injection; Levamisole: collection 14 days post exposure to infected fish and administration of the levamisole injection. 
lactate spike occurs under conditions of limited oxygen available for aerobic cellular metabolism, initiating gluconeogenesis from the lactate (OLSEN et al., 1995). The levamisole administered permitted a significant decrease in the high lactate levels when compared to the parasitized fish group.

In this research, the injectable levamisole was selected for the intense symptoms revealed during the treatment of the L. jocu. In fact, HANG et al. (2014) utilized the identical concentration of injectable levamisole ( $5 \mathrm{mg} \mathrm{kg}^{-1}$ live weight), and reported a positive effect on the catfish (Pangasianodon hypophthalmus) defense mechanisms during a bacterial infection treatment. One of the reasons for the choice of levamisole as a determinant factor was because it has been recognized as an immunostimulant, which apart from positively raising the productivity also facilitates the decrease or total ban on the employment of antibiotics, a crucial advantage in the aquatic culture systems (ZANON et al., 2014).

This study revealed important biochemical and hematological changes in the Neobenedenia melleni-infected dog snapper (Lutjanus jocu). Treatments performed with freshwater baths related to the administration of injectable levamisole revealed therapeutic efficacy in several parameters post treatment for 14 days.

\section{ACKNOWLEDGEMENTS}

To Coordenação de Aperfeiçoamento de Pessoal de Nível Superior (CAPES) - Financing Code 001, for supporting the first author with postgraduate fellowship. To Fundação de Amparo à Pesquisa e Inovação do Espírito Santo (FAPES) and CAPES supporting the second author (PROFIX FAPES/CAPES09/2014, process no. 72358173). To FAPES for financial support (process no. 698/2016, FAPES/ SEAG no. 06/ 2015-PPE Agro).

\section{DECLARATION OF CONFLICT OF INTERESTS}

The authors declare no conflict of interest. The founding sponsors had no role in the design of the study; in the collection, analyses, or interpretation of data; in the writing of the manuscript, and in the decision to publish the results.

\section{AUTHORS' CONTRIBUTIONS}

All authors contributed equally for the conception and writing of the manuscript.

\section{REFERENCES}

BILLER-TAKAHASHI, J.D. et al. Levamisole promotes an adjuvant effect on the immunity of pacu (Piaractus mesopotamicus) when immunized with Aeromonas hydrophila, even when provided in the diet. Animal Feed Science and Technology, v.211, p.164-
173, 2016. Available from: <https:/www.sciencedirect.com/ science/article/pii/S037784011530064X > . Accessed: Oct. 19, 2018. doi: 10.1016/j.anifeedsci.2015.11.008.

DEL RIO-ZARAGOZA, O.B. et al. Haematological and gill responses to an experimental infection of dactylogyrid monogeneans on the spotted rose snapper Lutjanus guttatus (Steindachner, 1869). Aquaculture Research, v.41, n.11, p.15921601, 2010. Available from: <https://onlinelibrary.wiley.com/ doi/full/10.1111/j.1365-2109.2009.02471.x>. Accessed: Mar. 19, 2019. doi: 10.1111/j.1365-2109.2009.02471.x.

DEL RIO-ZARAGOZA, O.B. et al. Hematological characteristics of the spotted rose snapper Lutjanus guttatus (Steindachner, 1869) healthy and naturally infected by dactylogyrid monogeneans. Tissue and Cell, v.43, n.3, p.137-142, 2011. Available from: $<$ https://www.sciencedirect.com/science/article/abs/pii/ S0040816611000085>. Accessed: Oct. 19, 2018. doi:10.1016/j. tice.2011.01.002.

ERNST, I.; WHITTINGTON, I.D. Hatching rhythms in the capsalid monogeneans Benedenia lutjani from the skin and $B$. rohdei from the gills of Lutjanus carponotatus at Heron Island, Queensland, Australia. International Journal for Parasitology, v.26, n.11, p.1191-1204, 1996. Available from: <https://www. sciencedirect.com/science/article/abs/pii/S002075199600118X>. Accessed: Oct. 19, 2018. doi:10.1016/S0020-7519(96)00118-X.

FAJER-ÁVILA, E.J. et al. Effectiveness of treatments against eggs, and adults of Haliotrema $s p$. and Euryhaliotrema $s p$. (Monogenea: Ancyrocephalinae) infecting red snapper, Lutjanus guttatus. Aquaculture, v.264, n.1-4, p.66-72, 2007. Available from: <https:/www.sciencedirect.com/science/article/abs/pii/ S0044848606009264>. Accessed: Oct. 19, 2018. doi: 10.1016/j. aquaculture.2006.12.035.

HANG, B.T.B. et al. Can immunostimulants efficiently replace antibiotic in striped catfish (Pangasianodon hypophthalmus) against bacterial infection by Edwardsiella ictaluri? Fish \& Shellfish Immunology, v.40, n.2, p.556-562, 2014. Available from: <https:// www.ncbi.nlm.nih.gov/pubmed/25120215>. Accessed: Oct. 19, 2018. doi: 10.1016/j.fsi.2014.08.007.

KERBER, Claudia Ehlers et al. First record of Neobenedenia melleni (Monogenea: Capsalidae) in sea-farmed cobia (Rachycentron canadum) in Brazil. Revista Brasileira de Parasitologia Veterinária, v.20, n.4, p.331-333, 2011. Available from: <http://www.scielo.br/ scielo.php?script=sci_arttext\&pid=S1984-29612011000400013>. Accessed: Oct. 19, 2018. doi: 10.1590/S1984-29612011000400013.

KUMAR, S. et al. Effects on haematological and serum biochemical parameters of Pangasianodon hypophthalmus to an experimental infection of Thaparocleidus sp. (Monogenea: dactylogyridae). Experimental parasitology, v.188, p.17, 2018. Available from: <https:/www.ncbi.nlm.nih.gov/ pubmed/29501694>. Accessed: Oct. 19, 2018. doi: 10.1016/j. exppara.2018.02.007.

LIANG, K.S. et al. Treatment of cultured golden snapper, Lutjanus johni Bloch, infected with monogeneans. Aquaculture, v.106, n.1, p.1-8, 1992. Available from: <https:/www.sciencedirect.com/ science/article/abs/pii/004484869290244F > . Accessed: Mar. 19, 2019. doi: 10.1016/0044-8486(92)90244-F.

LINDEMAN, K. et al. Lutjanus jocu. The IUCN Red List of Threatened Species 2016: e.T190221A1944443, 2016. 
Available from: <http://dx.doi.org/10.2305/IUCN.UK.2016-1.RLTS. T190221A1944443.en>. Accessed: Oct. 19, 2018.

OLSEN, Y. et al. Metomidate anaesthesia in Atlantic salmon, Salmo salar, prevents plasma cortisol increase during stress. Aquaculture v.134, n.1-2, p.155-168, 1995. Available from: <https://www. sciencedirect.com/science/article/abs/pii/004484869500008P $>$. Accessed: Oct. 19, 2018. doi: 10.1016/0044-8486(95)00008-P.

PETRILLO, T.R. et al. Influence of dexamethasone and levamisole on macrophage recruitment, giant cell formation and blood parameters in the tropical fish Piaractus mesopotamicus. Bioscience Journal, v.33, n.4, 2017. Available from: <http://www.seer.ufu.br/ index.php/biosciencejournal/article/view/33016>. Accessed: Oct. 19, 2018. doi: 10.14393/BJ-v33n4a2017-33016.

SANCHES, E.G. et al. Occurrence and treatment of monogenoides in fingerlings of florida pompano (Trachinotus carolinus) cultivated experimentally in the north area of the state of São Paulo. Revista Brasileira de Parasitologia Veterinária, p.1-4, 2007. Available from: <https://repositorio.unesp.br/handle/11449/453>. Accessed: Oct. 19, 2018.

SILVA, F.C. et al. First record of Neobenedenia "melleni"-like species (Monogenea: Capsalidae) in Goliath grouper Epinephelus itajara in Brazil. Revista Brasileira de Parasitologia Veterinária, v.23, n.2, p.248-250, 2014. Available from: <http://www.scielo.br/ scielo.php?script=sci_arttext\&pid=S1984-29612014000200248>. Accessed: Oct. 19, 2018. doi: 10.1590/S1984-29612014025.

ZANON, R.B. Dietary Levamisole as immunostimulant for striped surubim, Pseudoplatystoma reticulatum. Journal of the World Aquaculture Society, v. 45, n. 6, p. 672-680, 2014. Available from: $<$ https://onlinelibrary.wiley.com/doi/full/10.1111/ jwas.12156>. Accessed: Oct. 19, 2018. doi:10.1111/jwas.12156.

Ciência Rural, v.49, n.9, 2019. 